\title{
Performance of a Biodiesel Fuelled Single Cylinder Electronic Injection Compression Ignition Engine
}

\author{
Ganesh DB ${ }^{1^{*}}$ and Kumarappa $\mathrm{S}^{2}$ \\ ${ }^{1 *}$ Department of Mechanical Engineering, GM Institute of Technology, Davangere-577006, \\ Karnataka, India \\ ${ }^{2}$ Department of Mechanical Engineering, Bapuji Institute of Engineering and Technology, \\ Davangere-577004, Karnataka, India
}

\begin{tabular}{|c|c|}
\hline Abstract & Article Information \\
\hline \multirow{3}{*}{$\begin{array}{l}\text { High pressure electronic injection systems nowadays allow a very high degree of } \\
\text { flexibility in the timing and pressure control of fuel injection, which can be used to } \\
\text { obtain significant reduction in engine emission and improvement in engine } \\
\text { performance. In this study an electronic direct fuel injection single cylinder diesel } \\
\text { engine was used. The engine was operated on biodiesel produced from Jatropa. } \\
\text { Injection timings were changed to study their influence on performance and } \\
\text { emissions. The results have been compared with } 20 \text { percent biodiesel blend and } \\
\text { neat diesel operation. Advancing the injection timing and increasing the injector } \\
\text { opening pressure increase the brake thermal efficiency and reduce } \\
\text { hydrocarbons (HC) and smoke emissions significantly. }\end{array}$} & $\begin{array}{ll}\text { Article History: } \\
\text { Received }: 05-03-2013 \\
\text { Revised }: 30-03-2013 \\
\text { Accepted }: 31-03-2013 \\
\end{array}$ \\
\hline & $\begin{array}{l}\text { Keywords: } \\
\text { Jatropa } \\
\text { Biodiesel } \\
\text { Performance } \\
\end{array}$ \\
\hline & $\begin{array}{l}{ }^{*} \text { Corresponding Author: } \\
\text { Ganesh DB } \\
\text { E-mail: ganesh_db@yahoo.com }\end{array}$ \\
\hline
\end{tabular}

\section{INTRODUCTION}

An increasing demand for diesel engines is growing rapidly due to their fuel efficiency. The acute necessity for greater fuel economy, low toxic exhaust gas emissions, along with the reduction in diesel engine noise cannot be achieved by using mechanically governed fuel injection systems. In the past, the marked increase in the computing power on the microcontrollers available in the market has made it possible for the electronic diesel control to comply with modern diesel fuel injection system (Soorajith \& Vinu, 2004). To conduct laboratory scale experiments on a single cylinder engine, the control for the fuel injection variables and the fuel pressure are to be made flexible. As such, an electronic control unit for the system was designed by which the variables like injection timing, duration, pressure and multiple injection strategies can be easily regulated and controlled (Helmut, 2002). With an advanced injection timing there is more time available for mixture formation, this can lead better combustion and improved performance and also reduction in $\mathrm{HC}$ and Carbon Monoxide (CO) emissions. Increased injector opening pressure has significant effect on the performance and emissions of diesel engine of diesel engines. An increase of injection pressure is found to enhance the atomization at the nozzle outlet, resulting in a more distributed vapour, hence batter mixing. When the injection pressure is increased fuel particle diameter reduces. Since mixing of fuel and air become better during the ignition delay period, $\mathrm{HC}$ and smoke levels will reduce (Henein et al., 2002).

Energy is an essential requirement for economic and social development of any country. Hence, it has become imperative to find suitable fuels, which can be produced. Biodiesel produced from varieties of edible and non-edible seeds is one type of such initiative, which has been projected as alternative to diesel fuel and is gaining more and more attention during recent times. One alternative is Jatropa. The fuel properties of biodiesel samples met the specifications of fuels specified for diesel engines (Bureau of Indian Standards New Delhi, 1998). The properties of the biodiesel derived from Jatropa have been determined and summarized in Table 1. 
Ganesh and Kumarappa

Table 1 Fuel properties of biodiesel sample and diesel sample.

\begin{tabular}{cccc}
\hline $\begin{array}{c}\text { SI } \\
\text { No }\end{array}$ & Fuel properties & Biodiesel & Diesel \\
\hline 1 & Density $\left(\mathrm{kg} / \mathrm{m}^{3}\right)$ & 900 & 855 \\
2 & $\begin{array}{c}\text { Kinetic Viscosity } \\
\text { at } 40^{0} \mathrm{C}(\mathrm{c} . \text { St.) }\end{array}$ & 5.42 & 2.2 \\
3 & $\begin{array}{c}\text { Higher Heating } \\
\text { Value }(\mathrm{MJ} / \mathrm{kg})\end{array}$ & 37.24 & 45.4 \\
4 & Flash Point $\left({ }^{0} \mathrm{C}\right)$ & 105 & 55 \\
5 & Pour Point $\left({ }^{0} \mathrm{C}\right)$ & -4 & -18 \\
\hline
\end{tabular}

MATERIALS AND METHODS

Experimental Setup and Test Procedure

An electronically controlled four-stroke-single cylinder direct fuel injection (EDI) $\mathrm{Cl}$ engine was
Sci. technol. arts Res. J., Jan-Mar 2013, 2(1): 69-73

used which was developed in our laboratory. The schematic diagrams of the complete experimental setup test rig with electronic direct fuel injection (EDI) system are shown in Figure 1. The specifications of engine is given in Table 2.

This work aims to study in detail through experiments the influence of injection timing and injection pressure on the performance, emissions and combustion characteristics of EDI engine. Experiments were done at a constant speed of 1500 rpm with diesel, B20 and biodiesel. Parameters like injection timing and injection pressure were varied. Experimental results of brake thermal efficiency, $\mathrm{HC}, \mathrm{CO}$, NOx, smoke levels and heat release rate are presented and compared with that of diesel.

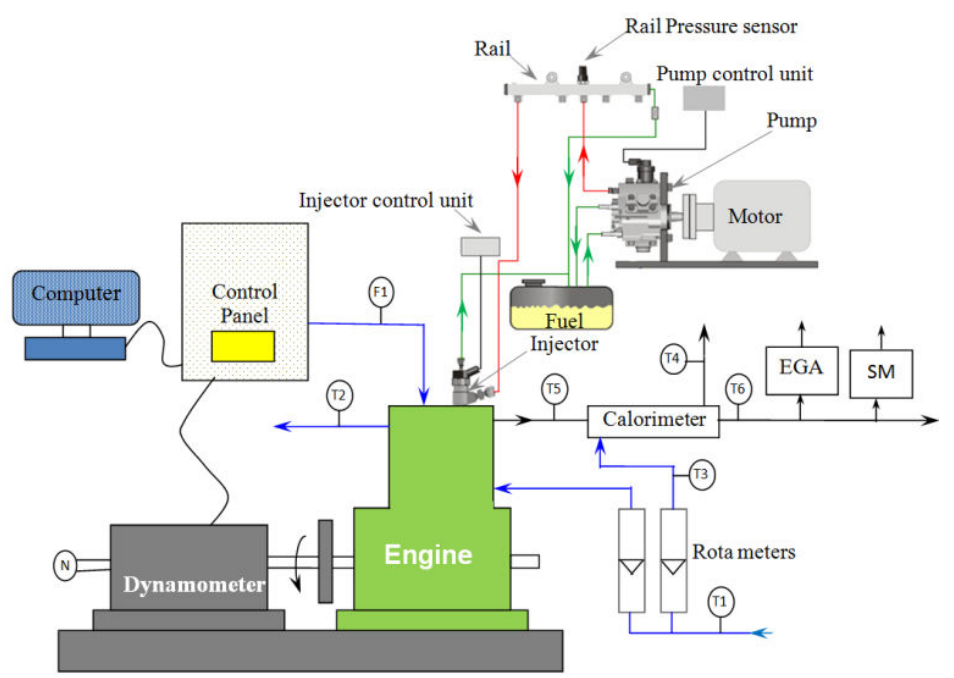

Key:

T1, T3 - Inlet Water Temperature.

T2 - Outlet Engine Jacket Water

Temperature

T4 - Outlet Calorimeter Water

Temperature

T5 - Exhaust Gas Temperature before

Calorimeter

T6 - Exhaust Gas Temperature after

Calorimeter,

F1 - Fuel Flow DP (Differential Pressure) unit

- RPM Decoder,

EGA - Exhaust Gas Analyzer,

SM - Smoke meter

Figure 1: Schematic diagram of experimental set up of $\mathrm{Cl}$ engine test rig with EDI system.

Table 2: Engine of specifications.

\begin{tabular}{cll}
\hline SI. No. & \multicolumn{1}{c}{ Parameters } & \\
\hline 1 & Make & Kirloskar, TV1 \\
2 & Type & Four stroke, water-cooled, OHV, Direct injection, Cl engine \\
3 & No. of cylinders & One \\
4 & Bore $\times$ Stroke & $87.5 \mathrm{~mm} \times 110 \mathrm{~mm}$ \\
5 & Compression ratio & $7.5: 1$ \\
6 & Rated power & $5.2 \mathrm{~kW} @ 1500 \mathrm{rpm}$ \\
7 & Dynamometer & Eddy current \\
8 & Fuel tank & Capacity 15 lit. with glass fuel metering column \\
9 & Air Box ( surge tank ) & M S fabricated with orifice meter and manometer \\
10 & Piezo sensor & Range 250 bar, with low noise cable \\
11 & Crank angle sensor & Resolution $1^{0}$, Speed 5000 rpm with TDC pulse \\
12 & Add on ADC & Resolution 12 bit , 8/16 input, Mounting PCl slot \\
\hline
\end{tabular}


Ganesh and Kumarappa

\section{RESULTS AND DISCUSSIONS}

The engine was always run at a constant speed. All these experiments were done at a full load. The injection pressure was kept constant at 800 bar by controlling the pump flow and the pressure regulator valve on the rail.

\section{Brake Thermal Efficiency}

The effect of injection timing on brake thermal efficiency for EDI system operation with diesel, biodiesel and blend B20 at five injection timings is
Sci. technol. arts Res. J., Jan-Mar 2013, 2(1): 69-73

shown in Figure 2. The brake thermal efficiency reduces with retarding the injection timing (Banapurmath, 2009). It is also seen that the maximum values of thermal efficiency could have been higher if a matched injector can be used. The maximum brake thermal efficiency reached was $33 \%$ and $31.00 \%$ for diesel and B20 respectively and $29.4 \%$ for biodiesel (B100) at injection timing of $340^{\circ} \mathrm{CA}$ which is higher than the conventional system even though the injector is not matched. Thus the EDI system is able to deliver higher thermal efficiencies.

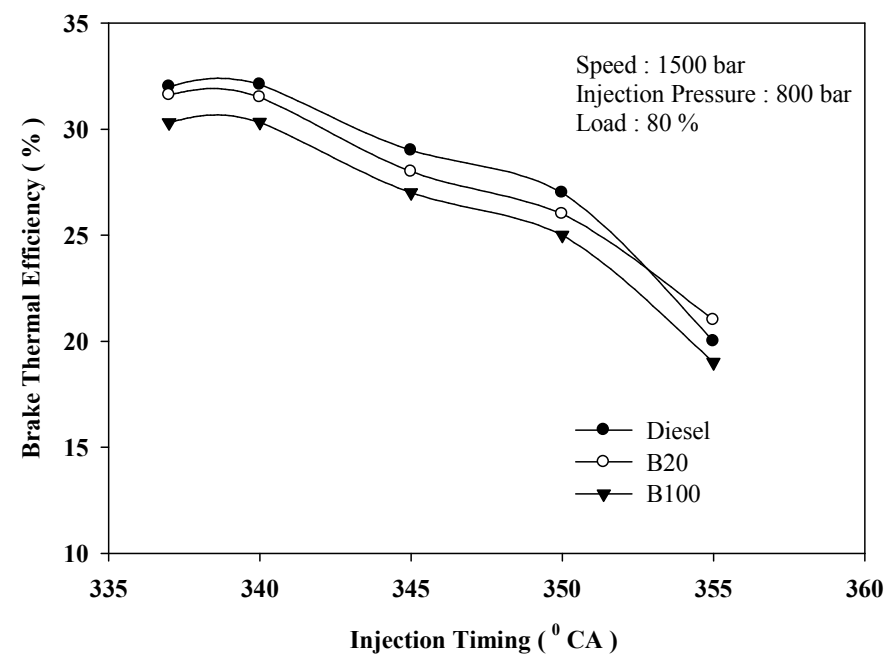

Figure 2: Effect of injection timing on brake thermal efficiency.

\section{$\mathrm{HC}$ and $\mathrm{CO}$ Emissions}

Figures 3 and 4 shows effect of injection timing on $\mathrm{HC}$ and $\mathrm{CO}$ emissions for diesel, biodiesel and blend B20. $\mathrm{HC}$ levels increase as the timing is retarded due to the increase in the premixed burn fraction that occurs on account of the reduced ignition delay (Agarwal, 2010). The $\mathrm{HC}$ levels are high because the injection system is not matched and wall wetting effects dominate. $\mathrm{CO}$ emissions also show similar trends. In fact as the injection timing is retarded, the brake thermal efficiency also falls and for the same power output this increases the amount of fuel delivered. This is also a reason for the increase in the CO level.

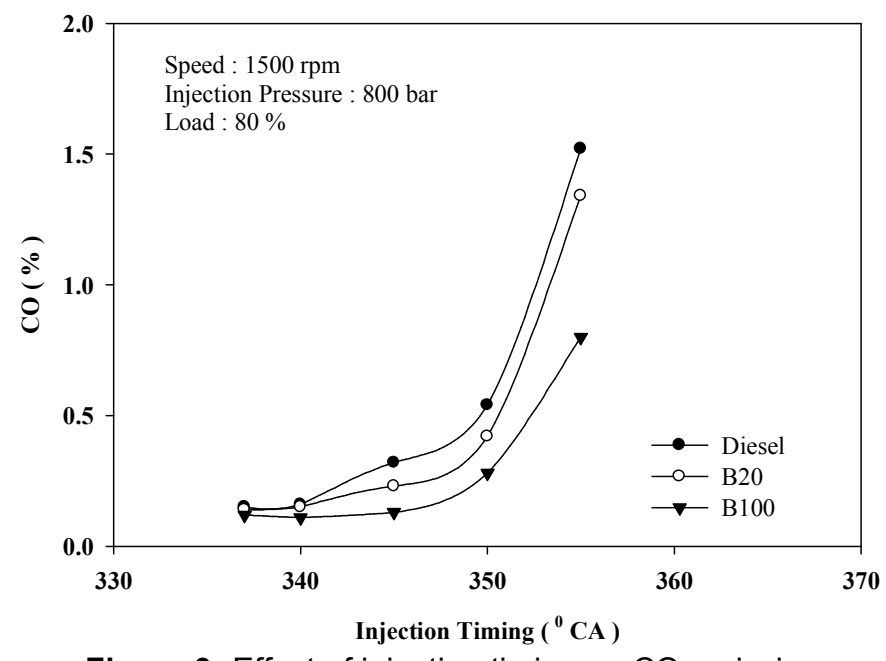

Figure 3: Effect of injection timing on $\mathrm{CO}$ emission. 


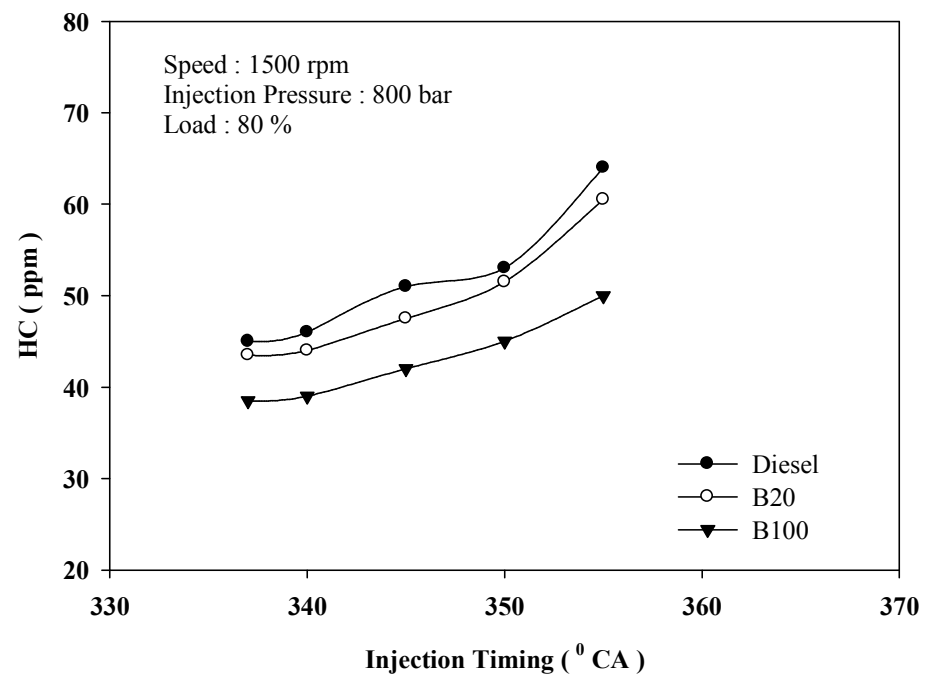

Figure 4: Effect of injection timing on $\mathrm{HC}$ emission.

\section{NOx Emissions}

The effect of injection timing on emission of nitrogen oxides for EDI system operation with diesel, biodiesel and blend B20 at five injection timings is shown in Figure 5. In general retarded injection results in substantial reduction in

nitrogen oxide emissions. As the injection timing is retarded, the combustion process gets retarded. Nitrogen oxide concentration levels are lower as the peak temperature is lower (Gajendra Babu, 2007).

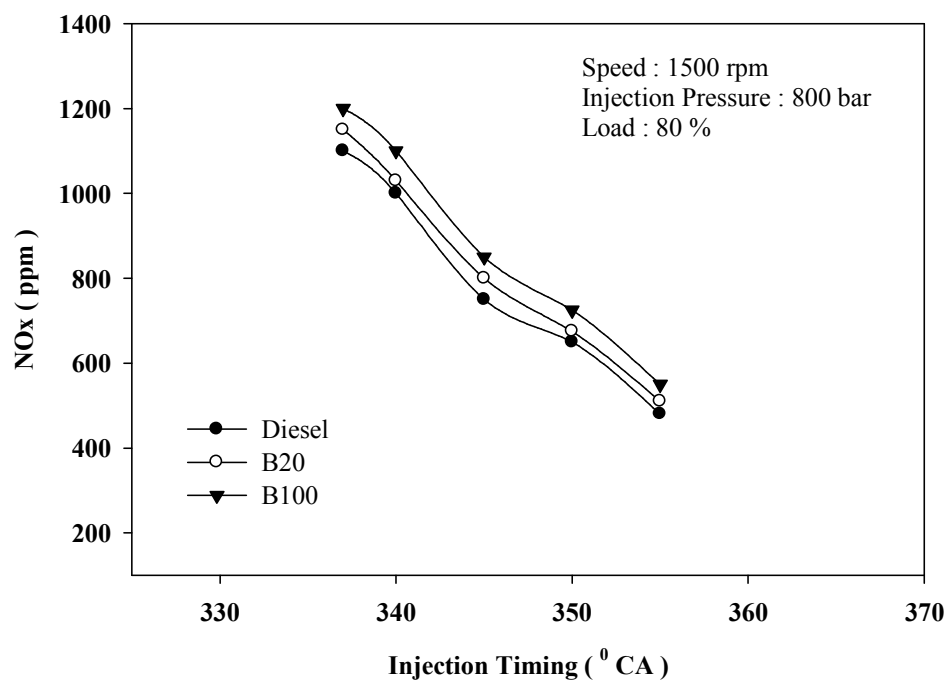

Figure 5: Effect of injection timing on NOx emission

\section{Smoke Opacity}

The effect of injection timing on smoke opacity for EDI system operation with diesel, biodiesel and blend B20 is shown in Figure 6. The smoke emission generally increases as the injection timing is retarded. The reasons for incomplete combustion are incorrect air-fuel ratio and improper mixing. Formation of smoke is basically a process of conversion of molecules of hydrocarbon fuels into particles of soot. The lesser smoke opacity of biodiesel are mainly due to emission of lower molecules of hydrocarbons and particulate. 


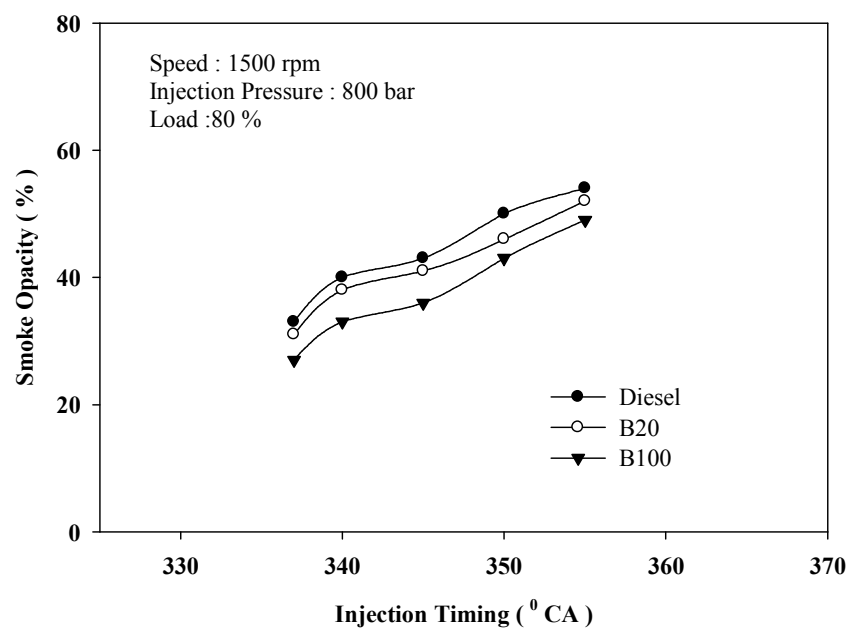

Figure 6: Effect of injection timing on smoke opacity

\section{Combustion Parameters}

The ignition delay is reduced as the timing is advanced. As the injection timing is advanced the peak heat release rate increases and the diffusion combustion portion also becomes less dominant. These are expected trends and indicate that the developed system is able to work satisfactorily.

Heat release profile can produced valuable information about combustion. Both a premixed combustion and diffusion combustion can be observed in this experiment. Shift of the start of combustion is consistent with change start of injection. The advanced start of combustion yield longer residence time and higher in-cylinder temperature, leading to an increase in NOx emissions.

The peak pressure reduces as the injection is retarded due to reduces heat release rates and also retarded combustion. At very retarded timings we see that combustion occurs after TDC even.

\section{CONCLUSIONS}

The engine is operated with diesel, B20 and biodiesel at injection timings of $355^{\circ} \mathrm{CA}, 350^{\circ}$ $\mathrm{CA}, 345^{\circ} \mathrm{CA}, 340^{\circ} \mathrm{CA}$ and $337^{\circ} \mathrm{CA}$. The injection timing $340^{\circ} \mathrm{CA}$ was found to be optimum for all the fuels tested. Higher injection opening pressures were found suitable for operating $\mathrm{Cl}$ engine with biodiesel. At optimum injection opening pressure of 800 bar, the brake thermal efficiency is improved. $\mathrm{HC}, \mathrm{CO}$ and smoke emissions are reduced. However, there was a marginal increase in NOx emission.

\section{REFERENCES}

Agarwal, A. K. (2010). Comparative performance, emission and combustion characteristics of RiceBran oil and its biodiesel in a transportation diesel engine, Journal of Engineering for Gas Turbines and Power, 132, 064503-1.

Banapurmath N.R., Tewari, P.G. and Hosmath, R.S. (2009). Effect of biodiesel from Honge oil and its blends with diesel when directly injected at different injection pressures and injection timings in singlecylinder water-cooled compression ignition engine. Proceedings of the IMechE Vol.223 part A: Journal of Power and energy, 31-40.

Bureau of Indian Standards (1998). "Method of Test for Petroleum and its products" IS 1448 (P:16, P:6, $P: 20, P: 25)$.

Gajendra Babu, M.K. (2007). Studies on performance and Exhaust Emissions of a $\mathrm{Cl}$ Engine Operating on Diesel and Diesel Biodiesel Blends at Different Injection Pressure and Injection Timings. Society of Automotive Engineers, Paper No.; 2007-01-0613, USA.

Helmut Randoll (2004). Technology for Electronic Diesel control, SAE 2004 Indian Mobility Conference, Proceedings of third international conference, 2004-28-0063 pp.412-417.

Henein, N. A., Lai, M.C., Singh, I.P., Zhong, L and Han, J. (2002). Characteristics of a common rail diesel injection system under pilot and post injection modes, SAE paper No. 2002-01-0218, 597-609.

Soorajith, R. and Vinu, H.R. (2004). Electronic Diesel control-A Strategy for Euro 3 optimization, SAE 2004 Indian Mobility Conference, Proceedings of third international conference, 2004-28-0025, 164168. 